\title{
AVALIAÇÃO DA EFICIÊNCIA DE ENXAGUATÓRIOS BUCAIS SOBRE A INATIVAÇÃO DE STREPTOCOCCUS SP. E CANDIDA ALBICANS IN VITRO
}

\author{
Ana Paula Barros de Jesus ${ }^{1}$ \\ Daiane Albuquerque Ribeiro Reis Silva² \\ Julierme de Siqueira Farias ${ }^{3}$ \\ José Eduardo Freitas ${ }^{4}$ \\ Aline Francisca Souza ${ }^{5}$
}

\begin{abstract}
Resumo: A sobrevivência de micro-organismos patogênicos na cavidade bucal depende da habilidade de se aderirem ao dente e sintetizarem placas bacterianas, formadas a partir de resíduos da má higienização. Para evitar a formação das placas bacterianas, além da higienização mecânica, podem ser aplicados enxaguatórios bucais, que inibem o crescimento de patógenos. Ao considerar a grande diversidade de marcas de enxaguatórios bucais no mercado, o presente trabalho visou avaliar quatro das principais marcas, quanto à eficácia in vitro na inibição de Streptococcus sp. e Candida albicans. Para tanto, foram utilizados os princípios ativos Clorexidina 0,12\%, Triclosan e Fluoreto de Sódio, Cloreto de Cetilpiridínio e Timol, empregado o método de difusão em ágar, para avaliação da formação do halo de inibição. Os melhores resultados obtidos na inibição dos micro-organismos testados foram Clorexidina 0,12\% e Triclosan e Fluoreto de Sódio.
\end{abstract}

Palavras-chave: Enxaguatório; antisséptico; periondontite; placa bacteriana.

\footnotetext{
1 Licenciatura em Biologia/UNIFATEA, Brasil. E-mail: ana.barros31@hotmail.com.

2 Licenciatura em Biologia/UNIFATEA, Brasil. E-mail: daianearibeirors@bol.com.br.

3 Licenciatura em Biologia/UNIFATEA, Brasil. E-mail: julierme_bob@hotmail.com.

4 Licenciatura em Biologia/UNIFATEA, Brasil. E-mail: zee.freitas@ibest.com.br.

5 Docente do Curso de Licenciatura em Biologia/UNIFATEA, Brasil. E-mail: alinefsmga@gmail.com.
} 